\title{
Electrolytic Treatment of ICPP Sodium-Bearing Waste Simulant (U)
}

by

D. T. Hobbs

Westinghouse Savannah River Company

Savannah River Site

Aiken, South Carolina 29808

\section{DISCLAIMER}

\begin{abstract}
This report was prepared as an account of work sponsored by an agency of the United States Government. Neither the United States Government nor any agency thereof, nor any of their employees, makes any warranty, express or implied, or assumes any legal liability or responsibility for the accuracy, completeness, or usefulness of any information, apparatus, product, or process disclosed, or represents that its use would not infringe privately owned rights. Reference herein to any specific commercial product, process, or service by trade name, trademark, manufacturer, or otherwise does not necessarily constitute or imply its endorsement, recommendation, or favoring by the United States Government or any agency thereof. The views and opinions of authors expressed herein do not necessarily state or reflect those of the United States Government or any agency thereof.
\end{abstract}

DOE Contract No. DE-AC09-89SR18035

This paper was prepared in connection with work done under the above contract number with the U.S.

Department of Energy. By acceptance of this paper, the publisher and/or recipient acknowledges the U. S. Government's right to retain a nonexclusive, royalty-free license in and to any copyright covering this paper, along with the right to reproduce and to authorize others to reproduce all or part of the copyrighted paper. 


\section{DISCLAIMER}

Portions of this document may be illegible in electronic image products. Images are produced from the best available original document. 


\section{DISCLAIMER}

This report was prepared as an account of work sponsored by an agency of the United States Government. Neither the United States Government nor any agency thereof, nor any of their employees, makes any warranty, express or implied, or assumes any legal liability or responsibility for the accuracy, completeness, or usefulness of any information, apparatus, product, or process disclosed, or represents that its use would not infringe privately owned rights. Reference herein to any specific commercial product, process, or service by trade name, trademark, manufacturer, or otherwise does not necessarily constitute or imply its endorsement, recommendation, or favoring by the United States Government or any agency thereof. The views and opinions of authors expressed herein do not necessarily state or reflect those of the United States Government or any agency thereof.

This report has been reproduced directly from the best available copy.

Available to DOE and DOE contractors from the Office of Scientific and Technical Information, P.O. Box 62, Oak Ridge, TN 37831; prices available from (615) 576-8401.

Available to the public from the National Technical Information Service, U.S. Department of Commerce, 5285 Port Royal Road, Springfield, VA 22161. 
Keywords: Nitrate, Destruction, Idaho Falls, Salt, Solution, Acid,

Alkaline

Retention Time: permanent

\section{Electrolytic Treatment of ICPP Sodium-Bearing Waste Simulant}

December, 1994

Westinghouse Savannah River Company P.O. Box 616 Aiken, SC 29802

Prepared for the Department of Energy Office of Technology Development, Office of Environmental Management under Contract DE-AC09-88SR 18035 
WSRC-RP-94-1300

\title{
Electrolytic Treatment of ICCP Sodium-Bearing Waste Simulant
}

\author{
by

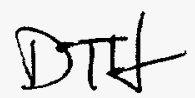 \\ D. T. Hobbs
}

December, 1994

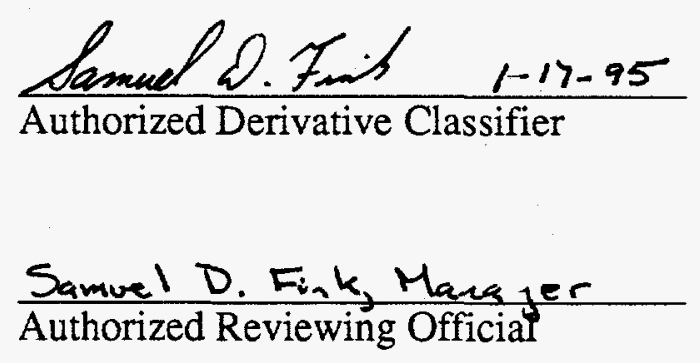

Savannah River Technology Center

Westinghouse Savannah River Company

Aiken, SC 29802

Prepared for the Department of Energy Office of Technology Development, Office of Environmental Management under Contract DE-AC09-88SR 18035 


\section{SUMMARY}

Two proof-of-principle tests were conducted to determine if nitrate can be destroyed electrochemically in a simulated Idaho Chemical Processing Plant (ICPP) SodiumBearing waste. Both tests demonstrated the destruction of nitrate as well as the removal of other metals in the simulant. Metals removal is believed to be due to precipitation as a result of a change in the $\mathrm{pH}$ of the waste solution from strongly acidic to highly alkaline and reduction to a metal or metal oxide. Although gas evolution at the cathode was visible during each test, there were no visible signs of $\mathrm{NO}_{\mathrm{x}}$ formation in either test.

\section{EXPERIMENTAL}

Electrochemical tests were carried out in a glass H-cell equipped with $2.5 \mathrm{~cm}^{2}$ platinum flag electrodes. The ICPP Sodium-Bearing Waste simulant, identified as SIMULANTIV, was placed in the catholyte compartment and a $5.0 \mathrm{M}$ sodium hydroxide solution was placed in the anolyte compartment. The electrodes were connected to a Hewlett Packard DC power supply (Model \# 6281A). The power supply was switched on and the voltage gradually increased from 2.0 to 3.5 volts. Gas evolution was immediately visible at both electrodes. Electrolysis was continued at 3.5 volts for the duration of the test. No attempt was made to measure the amount of gas or analyze the off-gas for composition. However, no evidence of the generation of $\mathrm{NO}_{\mathrm{x}}$ was observed during any test. Periodically, $5.0 \mathrm{~mL}$ samples of the catholyte were taken from the catholyte compartment and analyzed for nitrate concentration by ion chromatography and for elemental composition by inductively coupled plasma emission spectroscopy.

\section{RESULT AND DISCUSSION}

Two tests were conducted with the ICPP Sodium-Bearing Waste simulant. In the first test, the highly acidic simulant was electrolyzed directly as-received. In the second test, $50 \mathrm{wt} \%$ sodium hydroxide solution was added to the simulant resulting in a $\mathrm{pH}$ of 10.20 prior to electrolysis. In both tests, nitrate was observed to be destroyed as evidenced by the decrease in the nitrate concentration. The nitrate destruction rate was similar for both the highly acidic solution and the alkaline slurry (see Table I).

No $\mathrm{NO}_{\mathrm{x}}$ was observed in either experiment. Previous tests with strongly alkaline SRS and Hanford waste simulants have indicated that $\mathrm{N}_{2}, \mathrm{~N}_{2} \mathrm{O}$, or $\mathrm{NH}_{3}$ are the only nitrogencontaining products of the electrochemical reduction. The absence of $\mathrm{NO}_{2}$ in these tests is somewhat surprising since its presence has been reported in other tests with acidic nitrate solutions. Perhaps the generation rate is sufficiently slow that it is not observable, or the concentration of oxygen is so low in the catholyte that formation of the the readily visible brown gas, $\mathrm{NO}_{2}$, does not occur. 


\section{Table I. Nitrate Concentration and Percentage Destroyed During Electrolysis}

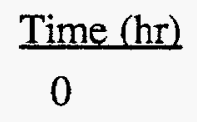

5.4

17.9

Time (hr)

0

6.7

16.7

\author{
Test \#1 - Acidic Waste Solution \\ Nitrate (M) \\ 4.34 \\ \% Destroved \\ 0 \\ 17 \\ 3.61 \\ 68
}

Test \#2 - Alkaline Waste Solution

${ }^{a}$ normalized based on before and after sodium concentrations determined by ICP/ES analysis.

Table II presents data on selected elements before and after each electrolysis test. Also included are the analytical results determined by INEL for the initial simulant solution. With the exception of $\mathrm{Fe}$ and $\mathrm{P}$, there was very good agreement between the two sets of analytical results. Water was added at the conclusion of the acidic simulant test, but not at the conclusion of the alkaline slurry test. To compare the before and after electrolysis concentrations, the after-electrolysis concentrations were normalized based on the before and after sodium concentrations.

Elements are removed during electrolysis as a result of two mechanisms: (1) electrolytic reduction and (2) precipitation due to a decrease in the acid concentration. Alkaline earth species $(\mathrm{Mg}, \mathrm{Ca}, \mathrm{Sr}$, and $\mathrm{Ba}$ ) are removed only by precipitation. In aqueous systems, only those reactions that have potentials greater than that of water will occur. The reduction potentials for the alkaline earths are more negative than water, and therefore, will not occur in an aqueous system (see Table III). However, as the acidity decreases, the alkaline earths precipitate as hydroxides. The greater degree of removal of these species in the higher $\mathrm{pH}$ simulant is consistent with a higher final hydroxide concentration.

Transition metals ( $\mathrm{Mn}, \mathrm{Fe}, \mathrm{Ni}, \mathrm{Cr}$, and $\mathrm{Mo}$ ) and main group metals $(\mathrm{Cd}, \mathrm{Pb}, \mathrm{Zn}, \mathrm{Al}$, and $\mathrm{Sn}$ ) were also removed. Based on standard state reduction potentials, the transition metals and $\mathrm{Cd}, \mathrm{Pb}, \mathrm{Zn}$, and $\mathrm{Sn}$ have reduction potentials more positive that water, and therefore could be electrochemically active. Aluminum has a lower reduction potential and therefore, is removed strictly by precipitation. Note that the removal of $\mathrm{Zn}, \mathrm{Al}, \mathrm{Sb}$, and $\mathrm{Sn}$ is reduced when the slurry becomes more strongly alkaline during electrolysis, which is consistent with the amphoteric behavior of these elements. In some cases, the removal may be the combination of both mechanisms. For example, $\mathrm{Cr}^{6+}$ is soluble at high $\mathrm{pH}$, whereas $\mathrm{Cr}^{3+}$ is not. Thus, removal of $\mathrm{Cr}^{6+}$ may occur by reduction of the $\mathrm{Cr}^{6+}$ to $\mathrm{Cr}^{3+}$ which can either precipitate as $\mathrm{Cr}(\mathrm{OH})_{3}$ or be further reduced to elemental $\mathrm{Cr}$. 
The increase in the Si concentration during electrolysis is believed to occur as the result of attack of the glass cell by the highly alkaline solution during the tests. Because of the variation in P concentrations between the LITCO and SRTC laboratories, the behavior of $P$ during electrolysis is difficult to interpret. It is possible that the observed variation is due to analytical errors from interfering species, or as a result of electrolysis. Phosphate has a reduction potential less than that of water, and therefore, would not be expected to undergo direct electrochemical reactions. However, sparingly soluble phosphate solids could be produced during electrolysis resulting in the decrease in $\mathrm{P}$ concentration in the acidic solution test. The variation in the $P$ concentration in the alkaline slurry test is not consistent with expected chemistry, and may be due to sample interferences and impurities in the $\mathrm{NaOH}$ used to neutralize the acidic solution.

\section{CONCLUSIONS AND RECOMMENDATIONS}

Proof-of-principle tests have demonstrated the destruction of nitrate and the removal of a large number of species in a simulated ICPP Sodium-Bearing waste solution. No evidence for the evolution of $\mathrm{NO}_{\mathrm{x}}$ was observed in either test. During electrolysis the $\mathrm{pH}$ of the waste solution increases resulting in the precipitation of ionic species that are not soluble at higher pHs. It is recommended that additional tests be carried out to determine the limiting current for nitrate destruction, to perform a more accurate mass balance, to determine off-gas products, and to demonstrate nitrate destruction in a laboratory-scale flow cell reactor.

\section{QUALITY ASSURANCE}

The experimental work reported in this document was carried out as a scoping task activity. Experimental data are recorded in laboratory notebook, WSRC-NB-91-184. Analytical results that were determined by the SRTC Analytical Services Group were performed under routine QC/QA requirements according to established analytical method procedures.

\section{ACKNOWLEDGMENTS}

This work was funded by the Office of Technology Development Office of Environmental Management through the Efficient Separations and Processing Integrated Program, Teresa B. Fryberger, Headquarters Program Manager, and James A. Wright, Cognizant Technical Program Officer. 
Table II. Elemental Composition of ICPP Sodium-Bearing Waste Simulant Before and After Electrolysis

Acidic Solution

Concentration $(\mathrm{mg} / \mathrm{L})$

\begin{tabular}{|c|c|c|c|c|c|}
\hline & \multicolumn{3}{|c|}{ Acidic Solution } & \multicolumn{2}{|c|}{ Alkaline Solution } \\
\hline & Before $^{a}$ & Before $^{b}$ & After $^{b, c}$ & Before ${ }^{b}$ & After ${ }^{b, c}$ \\
\hline $\mathrm{Ag}$ & nd & $<0.182$ & $<0.182$ & $<0.182$ & $<0.18$ \\
\hline As & nd & 10.5 & $<1.82$ & $<1.82$ & 4.13 \\
\hline $\mathrm{Se}$ & nd & 32.6 & $<9.1$ & $<9.1$ & 10.6 \\
\hline $\mathrm{Ca}$ & 1560 & 1560 & 562 & 30.6 & 0.571 \\
\hline $\mathrm{Cd}$ & 258 & 232 & 42.0 & 0.721 & 0.326 \\
\hline $\mathrm{Ce}$ & 56.4 & 50.1 & $<1.82$ & $<1.82$ & $<1.82$ \\
\hline $\mathrm{Co}$ & nd & $<0.364$ & $<0.364$ & $<0.364$ & $<0.364$ \\
\hline $\mathrm{Cu}$ & nd & $<0.091$ & $<0.091$ & $<0.091$ & $<0.091$ \\
\hline $\mathrm{Mg}$ & nd & 120 & 35.9 & 0.405 & $<0.091$ \\
\hline $\mathrm{Mn}$ & 796 & 796 & 197 & 1.94 & $<0.091$ \\
\hline $\mathrm{Pb}$ & 224 & 238 & $<1.82$ & $<1.82$ & 9.87 \\
\hline $\mathrm{Zn}$ & nd & 3.10 & 0.508 & $<0.091$ & 0.540 \\
\hline $\mathrm{Zr}$ & nd & 82.4 & $<0.455$ & 0.701 & $<0.455$ \\
\hline $\mathrm{Al}$ & 17500 & 15600 & 1.97 & 104 & 5700 \\
\hline $\mathrm{Ba}$ & nd & 0.519 & $<0.091$ & $<0.091$ & $<0.091$ \\
\hline $\mathrm{Fe}$ & 1520 & 368 & $<0.182$ & 1.18 & 0.976 \\
\hline $\mathrm{La}$ & nd & 2.03 & $<0.273$ & $<0.273$ & $<0.273$ \\
\hline $\mathrm{Li}$ & nd & $<0.091$ & $<0.091$ & $<0.091$ & $<0.091$ \\
\hline Mo & 141 & 101 & 0.499 & 51.1 & 35.4 \\
\hline $\mathrm{Na}$ & 29000 & 31700 & 31700 & 68700 & 68700 \\
\hline $\mathrm{Ni}$ & 127 & 124 & 3.62 & $<0.455$ & $<0.455$ \\
\hline $\mathrm{Sb}$ & nd & 31.2 & $<1.82$ & $<1.82$ & 9.71 \\
\hline $\mathrm{Sn}$ & nd & 7.28 & $<0.637$ & $<0.637$ & 2.63 \\
\hline $\mathrm{Sr}$ & 14.7 & 13.4 & 5.34 & 0.810 & $<0.091$ \\
\hline $\mathrm{Ti}$ & nd & 0.600 & $<0.091$ & $<0.091$ & $<0.091$ \\
\hline V & nd & 0.215 & $<0.091$ & $<0.091$ & $<0.091$ \\
\hline B & 182 & 191 & 35.0 & 87.3 & 71.0 \\
\hline $\mathrm{Cr}$ & 350 & 318 & $<0.364$ & 7.61 & 33.8 \\
\hline $\mathrm{P}$ & $<2.84$ & 97.4 & $<0.910$ & 2.11 & 120 \\
\hline $\mathrm{Si}$ & nd & 8.71 & 11.9 & $<0.546$ & 16.9 \\
\hline
\end{tabular}


Table III. Electrochemical Series for Species in the ICPP Sodium-Bearing Waste Simulant

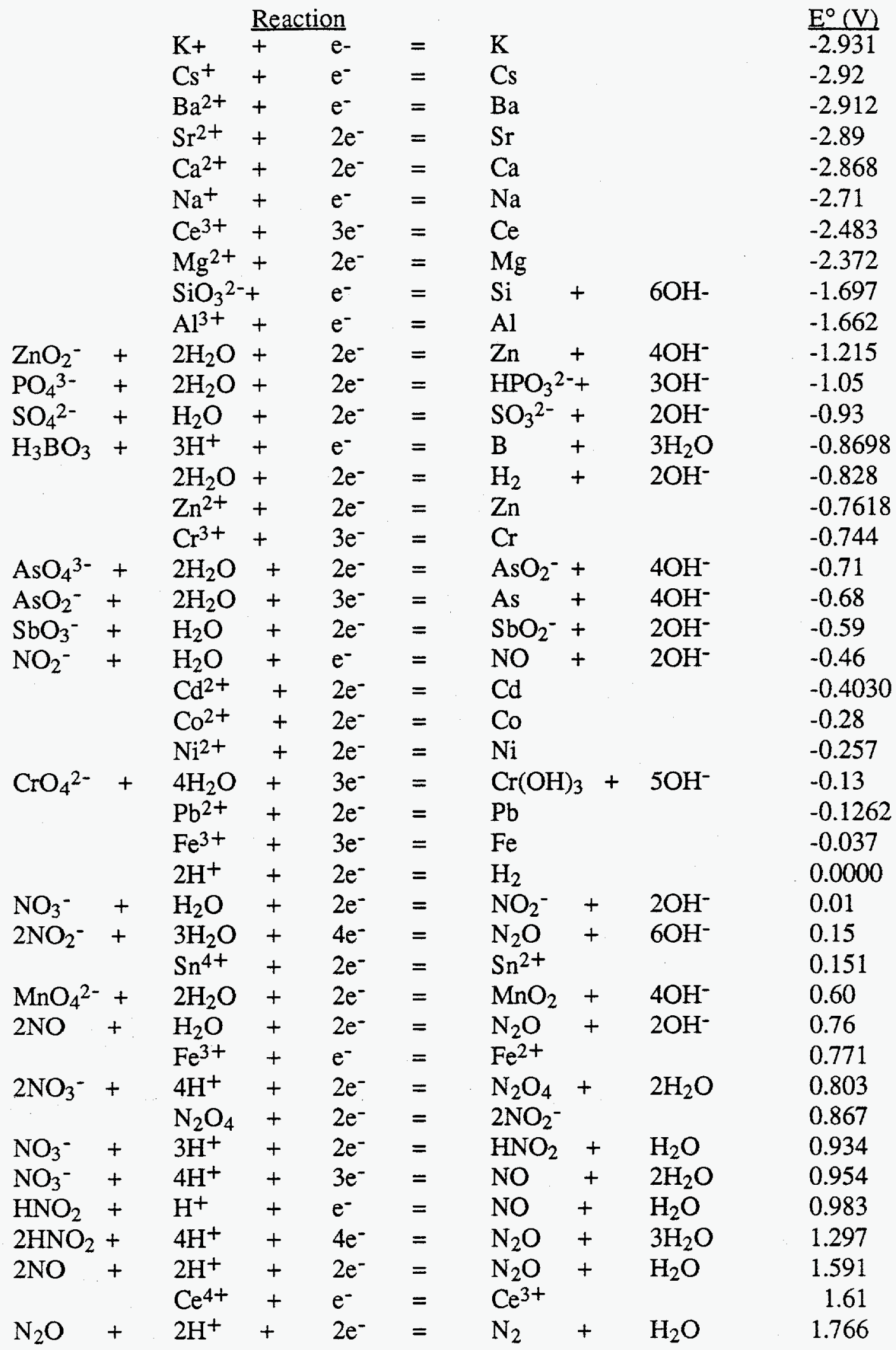


cc: T. B. Fryberger, DOE-HQ

J. A. Wright, DOE-SR, 703-A

M. G. Schwenker, DOE-SR, 704-H

W. L. Kuhn, PNL

J. E. Surma, PNL

P. A. Taylor, ORNL

K. Wendt, LITCO

W. L. Tamosaitis, 773-A

S. D. Fink, 773-A

R. F. Swingle, 773-A

IWT-LWP File, 773-A

TIM, 773-52A 